\title{
The Choral Cycle Six Songs to the Lines of R. Rilke by Paul Hindemith (some Style Features)
}

\author{
Lidiia L. Ravikovich* \\ Krasnoyarsk State Institute of Arts \\ 22 Lenin Str., Krasnoyarsk, 660049, Russia
}

Received 15.01.2017, received in revised form 13.07.2017, accepted 24.07.2017

\begin{abstract}
This article examines one of the most popular works of Paul Hindemith for a mixed chorus a cappella that is the cycle Six Songs to the Lines of R. Rilke, which vividly represents the creative style of the outstanding German master. Set to the texts of the original French poems by the Austrian poet, this cycle is distinguished by its stylistic unity, fresh sound and is an example of the deep organic nature of Hindemith's choral thinking as the basis of the compositional method. Each of the songs of the cycle presents a picture of nature, imbued with a lyrical light and brightly, emotionally and convincingly embodied by the composer. On the basis of the analysis of this work, the paper highlights such issues as the structural principles and interpretation of the musical form, the dramatic development of the cycle choruses and their dynamic profile, analyzes expressive means, in particular, the intonationmelodic and modal harmonic language of the work, its textural organization.
\end{abstract}

Keywords: composition, form, drama, tonality, harmony, texture.

DOI: 10.17516/1997-1370-0130.

Research area: culturology, art criticism.

In the extensive and multifaceted creative heritage of Paul Hindemith (1895-1963), vocal-symphonic and choral music occupies a significant place, which is far from an accident. It was in the first half of the $20^{\text {th }}$ century when there was a rapid development of cantata-oratorial and vocal-choral genres. During this period, their significant samples such as oratorios, cantatas, a cappella choirs of S. Taneev, S. Rakhmaninov, I. Stravinsky, A. Schoenberg, A. Webern, K. Orff, A. Honegger, D. Millau, F. Poulenc, B. Bartók, Z. Koday, K. Szymanowski appear. The process then continued in the 50s-70s, which led to a further rise and substantial renovation

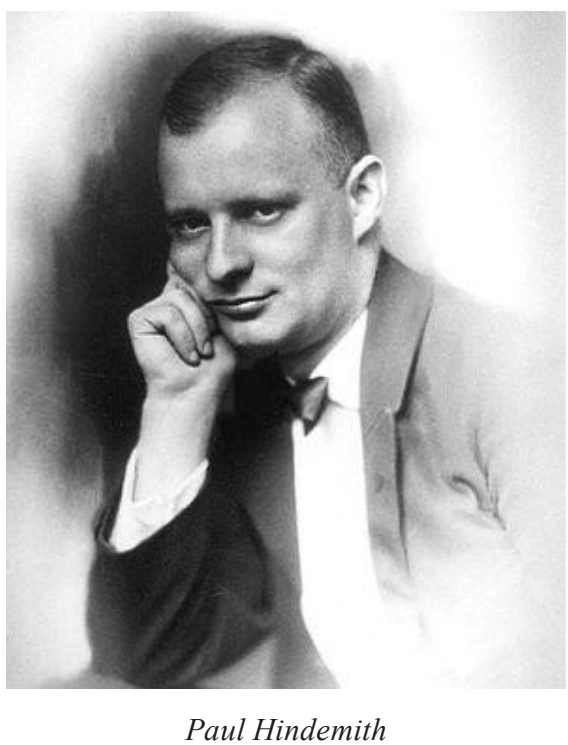

Paul Hindemith

(c) Siberian Federal University. All rights reserved

* Corresponding author E-mail address: 11ravikovich@list.ru 
of these genres. In A. Sokhor's opinion, “their revival in the $20^{\text {th }}$ century and the promotion of European music to the forefront were conditioned by the changed socio-historical conditions and the new social needs that ensued from here. Oratorio, cantata, choral cycle attracted the attention of composers because by their nature they were able to meet the requirements of the century" (Sokhor, 1980: 313).

Undoubtedly, this tendency was influenced by "the spirit of the post-war period - the thirst for life after the horrors and death of World War I" (Kostiuk, 2012: 65). Social cataclysms forced artists to take a fresh look at their art. They contrast underlined emotionality and illusory romanticism, the extremes of expressionism and impressionism with strict rigidity, harmony and dominance of the rational principle, which is reflected in the appeal to the choral genres, to the development of which Paul Hindemith, who was one of the biggest figures in the music of the $20^{\text {th }}$ century, made a huge contribution.

As is known, the composer was an indefatigable musical enlightener and teacher. $\mathrm{He}$ not only performed many concerts, performed on the radio, wrote music for the cinema, but also paid much attention to the mass musical education of broad sections of society. According to I.S. Fedoseev, "since the late 1920s, Hindemith was literally obsessed with the idea of creating a wide and serious repertoire for mass chamber music-making (Gebrauchsmusik). The composer confirmed this idea with all the subsequent creative practice, not being afraid of numerous reproaches in digression from the principles of "high" art, in deliberate simplification and primitivization and creating many works of this kind" (Fedoseev, 2010: 410).

Thus, Hindemith's writings include five different-scale cantatas, in which his aesthetic conception of the high ethical mission of music and the consequent moral responsibility of the artist-creator to art and society is most fully revealed. Among them is Madame Music to the words of M. Luther (1929), The Call of Young People to Study Music Diligently to the words of M. Agricola (1932), Suddenly the Day Comes to the lines of the Latin poem (1947), Fly, Fast Angels to the words of P. Claudel (1955), and The Mainz Procession to the words of K. Tsukmayer (1962). Hindemith's most important works in the field of vocal and symphonic music are also the oratorio The Continuous to the lines of G. Benn (1931) and the Requiem To the the Ones We Love ("When in the courtyard in front of the house the lilac bloomed this spring") to the lines of W. Whitman (1946), dedicated to the memory of A. Lincoln, F. Roosevelt and ordinary Americans who died on the fronts of the war.

Hindemith also created about fifty a cappella choirs for various compositions, among which there are such works as Five male choirs to the words of B. Brecht, W. Whitman and G. Benn (1930), Three male choruses to ancient anonymous texts and words of F. Nietzsche (1939), Six Songs for a mixed choir to the lines of R. Rilke (1939), Variations on the old dance song Old and Young for the male choir (1939), The Demon of the Gallows for the male chorus to the words F.D. O’Brien (1949), Twelve madrigals for the vocal ensemble to the words of J. Weinheber (1959). The last completed composition of Hindemith was the Mass for the mixed choir a cappella, in which the composer revives the old type of Catholic missa brevis, widespread among the masters of the $15^{\text {th }}-16^{\text {th }}$ centuries.

The most famous among these works are the Twelve madrigals to the verses by J. Weinheber and Six Songs for the original French poems by Rainer Maria Rilke, whose work attracted Hindemith for its philosophical, spiritual richness and religiosity. The leading theme of the lyrics of the Austrian poet is overcoming loneliness 
through love for people and merging with nature. In 1899-1900, Rainer Rilke visited Russia, where he communicated with L.N. Tolstoy, after which his poetry acquires a clear humanistic orientation, interpreting religion in the democratic spirit of medieval mystical teachings as the only force capable of giving meaning to human being.

The poet himself opposed the composers' desire to compose music to his texts, he saw his rivals in them. Rilke aversed the concert hall with the usual forms of music-making, the atmospherere of a large human gathering seemed to him hostile to genuine art. The poet believed that music should be heard in solitude or in the church. In addition, he saw a dangerous power that was alien to his verses in music, because the composer could treat unarmed verses as he pleased, for example, take their rhythm from them, change rhyme, break any line, destroy any sense of poetry with an incorrect accent.

Nevertheless, despite the views of Rilke, the composers often voiced his works. At the same time, using, as a rule, impressionistic colorfulness, they rarely managed to preserve the spiritual fullness of the lyrics of the Austrian poet.

Hindemith wrote several works to the lines of Rilke, such as the vocal cycle The Life of Mary (or. 27), Songs for Choral Circles (or. 43), Six Songs for a mixed choir a cappella (without opus). The texts selected by Hindemith for Six Songs are taken from the original French poems of the poet. It includes the following choirs: Fallow Deer, Swan, If Everything Passes, Spring, In Winter, Fruit Garden. The order of these choruses is not accidental: it embodies the philosophical views of the German master. The choirs Fallow Deer and Swan symbolize the ideal of purity and white. They create the illusion of something beautiful: tremulous happiness, dreams of love, secret doubts. Through the images of fallow deer and swan, Hindemith reveals to the listener the secrets of the human soul, for life without love and hope is empty and meaningless. But ... love, like a dream, dissipates to the morning and everything passes, leaving behind only a trace of grief and sadness.

The composer perceives the spring as an update, as a new "beautiful life". But with the passage of time, the "new life" also passes, this endless run of minutes cannot be stopped, it is ruthless, like the laws of nature, where month after month, year after year pass in succession. In the choir In Winter there is an allegorical meaning: winter means cold, suffering, old age and death...

Proceeding from the direction of Rilke's philosophical conception and the adequate reading by Hindemith, only bodily death overtakes man, both old and young. And again spring, spiritual renewal come. The human "I" finds a new existence, in this case it is not incorporeal: we are fascinated both by the beautiful flowering garden itself and its fruits. And everything around breathes with transparency, and this beauty is eternal, despite the adversity that surrounds our life with a gloomy halo. The choir Fruit Garden is permeated with eternal unshakable symbols, such as lace of shadows, mirror purity of the pond, the spring attached to the mighty roots.

The features of symbolism can be seen in the tonal structure of the works of Hindemith. It is known that the composer rejects the tried and true leitmotif system as obsolete, turned into a kind of musical game. At the same time, the author attaches special importance to tonal symbolism: he recalls the ancient custom that is the conditional arrangement of musicians about what mood and state is concealed in this or that tonality. The composer insists that in his system of tonal-emotional-semantic connections each tonal shift and each change gets its own strictly defined meaning. 
Let us consider the modal-tonal plan of the whole cycle:

$\begin{array}{cccccc}\text { № } 1 & \text { № } 2 & \text { № } 3 & \text { № 4 } & \text { № } 5 & \text { № 6 } \\ \text { A } & \text { E } & \text { G } & \text { As (Gis) } & \text { Es } & \text { G }\end{array}$

Obviously, starting from the tonal structure, the cycle can be divided into two parts: No. $1-3$ (A-E-G) and No. 4-6 (As (Gis) - Es - G). The second of them seems to repeat the tonal plan of the first, but in a slightly modified version: the first two tonalities are lowered by a half tone. Incidentally, it should be noted that this is the variant of the steps characteristic of the musical language of Hindemith. In addition, if we fix the main milestones of the modal-tonal structure of the cycle, we can find a sequence of two trichord turns ( $\mathrm{a}-\mathrm{e}-\mathrm{g}$, as $-\mathrm{es}-\mathrm{g})$, which reveals a connection with the melodic thinking of the composer. It is the trichord intonation that serves as the initial thematic grain and, undergoing various transformations, permeates the entire composition.

The G-dur tone in this opus is central, to which the two previous ones in both mini-cycles are directed. And this is not accidental; it carries the semantic meaning of everything idyllic. It is in this tonality that the choirs with deep philosophical content are written in: death, the end represent the beginning of something new, the spiritual life after death, the birth of a new man and the new in man (No. 3 If Everything Passes and No. 6 Fruit Garden).

The E-dur tone in the cycle carries the symbol of earthly life. Thus, the image of a swan (No. 2) acquires visible features; dreams are embodied in reality. It is this tonality that Hindemith associates with the appearance of Mary as born, lived and died in the name of her great son (it is enough to recall the vocal cycle The Life of Mary to the lines of R. Rilke). If E-dur is related to the terrestrial essence of the images, then its subdominant A-dur (No. 1) recalls their second essence, which is heavenly, divine. In this case, a fallow deer is a dream, revery, an embodiment of divine beauty and harmony.

The Es-dur tone is a symbol of purity, detachment, turning into lifelessness and eventually identical to death. In the chorus In Winter this tonality experiences this metamorphosis: from visible earthly purity to death and heavenly enlightenment.

The structure of As-dur bears hope, aspiration to perfection and doubt in a reality of unearthly dreams (No. 5 Spring). The voice of the earth, emanating from the mouth of nature, absorbing the appearance of the spring forest, the composer directs to the sky, in the hope that the higher powers will hear the magic song of the forest and carry sorrow away.

It should be noted that in the work the individual is invisibly present. Through his dreams, revery, moods we learn about the existence of a certain "I", which never appears during the whole cycle. In this you can see the clear influence of literature and philosophical trends of the early $20^{\text {th }}$ century. The invisible hero follows the plot outline and the dramatic development of the work as if from outside, outwardly not participating in it, but in fact being the leading point of reference. The thoughts and intentions of the hero are present in every issue of the cycle, but all the same he does not receive a physical, earthly incarnation.

Of particular interest is the architectonics of the choir of the cycle, distinguished by strict and clear proportions. In this work Hindemith uses traditional classical musical forms (simple binary, ternary forms), but treats them differently each time. Thus, the first chorus Fallow Deer is written in a simple ternary reprise form, the feature of which is that the exposition function in the choir is performed not by a period, but by a sentence (in German terminology it is called der Satz in contrast to 
Periode), which can be clearly presented in the form of a scheme:

$\begin{array}{ccc}\text { A } & \text { B } & \text { Al } \\ \text { A } & \text { fis }- \text { Cis } & \text { A } \\ 4 \text { t. } & 7 \text { t. } & 5 \text { t. }\end{array}$

The similar use of the der Satz sentence in the period function, as well as the miniature of the entire composition (16 bars) and the internal proportions of its parts $(4+7+5)$, give this structure a similarity to the period with the features of the reprise, where the second sevenstroke has a twofold function, namely, the second sentence of the period and the second part of a simple ternary form. This is natural for a period consisting of three sentences, in which the transition from the second sentence to the third is identical to the relation of the middle and the reprise. However, a complete analogy with the form of the period here is hampered by certain fundamental differences. First of all, the functions of individual parts are much more clearly defined in this choir, while its thematic system as a whole is emphatically three-staged. This dismemberment of the structure and a clear differentiation of the semantic functions of its elements generates discontinuity, which differs from a more coherent and monolithic flow of the period.

It is necessary to pay attention to modal harmonic means acting here as a dynamic factor that maximally contributes to the alignment of this form. Thus, the exposure and reprise are presented in the main tone of A-dur, while the middle part (t. 5-10) is a mid-unstable type structure, in which the modulations in the sixth and third stages (fis-moll and Cis-dur) are observed, which is characteristic of the middle sections of symmetric ternary forms. In addition, the location of the culmination at the point of the "golden section" (t. 10), the revival of the rhythmic side of the music (changing the meter, the movement of the eighth, the dotted rhythm, the triplet), as well as achieving the maximum in the dynamic amplitude (forte) resemble the prereprise phases in three-stage forms, where the center of gravity moves to the middle part, which is prevalent in the general architectonic scheme.

The composition of the second choir Swan is also noted for its originality. Here, Hindemith refers to a simple binary reprise form, in which the first part represents a period of non-repetitive structure, and the second part, equal in scale to the first one, contains the middle of the developing type and a modified reprise of the initial sentence.

The scheme is as follows:

\begin{tabular}{|c|c|c|c|}
\hline \multicolumn{2}{|c|}{$\mathrm{A}$} & \multicolumn{2}{c|}{$\mathrm{B}$} \\
\hline $\mathrm{a}$ & $\mathrm{b}$ & $\mathrm{c}$ & $\mathrm{a}_{1} / \mathrm{b}_{1}$ \\
\hline $\mathrm{E}-\mathrm{H}$ & $\mathrm{e}$ & $\mathrm{e}-\mathrm{C}$ & $\mathrm{E}$ \\
\hline $5 \mathrm{t}$. & $6 \mathrm{t}$. & $6 \mathrm{t}$. & $5 \mathrm{t}$. \\
\hline
\end{tabular}

A feature of this composition is its similarity to the old sonata form, which is typical of the composer. Thus, in the exhibition period, representing two sentences that are unequal in scope $(5+6)$, contrasting elements collide, that is, the tendency towards polarization of thematism is affected, which is due to the introduction of new melodic material, polyphonization of the texture, revitalization of the rhythm. Thanks to textured means and a bright change of harmonic coloring, this initial period becomes a harbinger of the sonata exposition, which is confirmed by further stages of development. The second part of the form splits into two phases, like the second part of the old sonata form with its complicated function of combining undeveloped development and reprise $(6+5)$.

Sonata features are particularly pronounced in the second phase, where the reprise has a synthetic character, combining the melodic material of both sentences of the initial period (t. 18-22). In addition, the general line of the dynamic development and the location of the general culmination (t. 16) at the foot of the reprise are also typical for sonata. 
Thus, in this chorus an organic combination of some features of the old sonata form with features of a simple binary structure is observed, which indicates the close connection of Hindemith with baroque music.

The composer's propensity for brevity also affects the third chorus of the cycle If Everything Passes, which is written, by analogy with the second, in a simple binary reprise form, but in contrast to it has more strict proportions:

\begin{tabular}{|c|c|c|c|}
\hline \multicolumn{2}{|c|}{ A } & \multicolumn{2}{c|}{ B } \\
\hline $\mathrm{a}$ & $\mathrm{b}$ & $\mathrm{c}$ & $\mathrm{b}_{1}$ \\
\hline $\mathrm{G}-\mathrm{e}$ & $\mathrm{G}$ & $\mathrm{C}$ & $\mathrm{G}$ \\
\hline $4 \mathrm{t}$. & $4 \mathrm{t}$. & $5 \mathrm{t}$. & $4 \mathrm{t}$. \\
\hline
\end{tabular}

Obviously, the first part is a typical eightcycle period $(4+4)$. In the second part, two stages are clearly differentiated: the middle (t. 9-13) and the reprise (t. 14-17), which almost literally repeats the second sentence of the initial period. Undoubtedly, there is a tendency to overcome the scale ratios of a simple binary form. The content and structure of the middle, which is thematically contrasting, contains the culmination at the point of the "golden section" (t. 13) and is the center of gravity of this composition, count in favor of this thesis. Nevertheless, the reprise does not reach the level of structural organization and "weight" that are necessary to ensure the equilibrium inherent in the ternary form.

The composition of the fourth choir Spring also has individual features. Its basis is a simple binary reprise structure, in which the first part is presented in the form of a period of non-repetitive structure $(3+4)$, variedly repeated, while the second part contains the middle of the contrast type and the reprise, which is a modified second sentence of the first part.

We give the scheme:

\begin{tabular}{|c|c|c|c|c|c|}
\hline \multicolumn{4}{|c|}{ A } & \multicolumn{2}{c|}{ B } \\
\hline $\mathrm{a}$ & $\mathrm{b}$ & $\mathrm{a}_{1}$ & $\mathrm{~b}_{1}$ & $\mathrm{c}$ & $\mathrm{b}_{2}$ \\
\hline As $-\mathrm{f}$ & As & As $-\mathrm{f}$ & As & gis & Gis \\
\hline $3 \mathrm{t}$. & $4 \mathrm{t}$. & $3 \mathrm{t}$. & $4 \mathrm{t}$. & $3 \mathrm{t}$. & $4 \mathrm{t}$. \\
\hline
\end{tabular}

Obviously, the initial period has a nonstandard construction, which causes peculiarities in the structure of the whole form. It consists of two sentences that are different in thematism and scale, the second of which (b), forming a wave of ascent and recession, contains a culmination and expands due to the descending sequent (t. 3-7). The three-fold implementation of this sentence as a result of a varied repetition of the initial period greatly enriches and enlarges the work. In this case, there is some "form of the second plan" that is a small "dispersed variational cycle" (the term by V.V. Protopopov). But however significant these variational relations may be, they still do not remove the definition of the basic type of form as a simple binary reprise.

The peculiarities of this composition should include its type of dramatic art that is a polyfigured type. If in the previous choirs one figured sphere was represented that is light contemplation, a vivid and poetic picturesqueness (images of the forest, the beauty of nature), then in the fourth chorus there is a figurative and emotional "deviation". The tranquil character of the first part and the reprise is contrasted with the episode "s", which contains a dramatic culmination that falls on the point of the "golden section" (t. 15-17). The brevity of recitative phrases, the abundance of pauses, the sharp change of color from major to minor (gis-moll after As-dur) contribute to the creation of gloomy character, which is certainly inspired by the images of the poetic text, "Hear, spring, we need to part again with you."

A similar (polyfigured) type of drama determines the convergence of this form with a ternary form, which is emphasized by the contrast of the emotional state and the musical material of the middle section, but, nevertheless, it cannot turn into a semantic center (in view of its brevity) and become a functionally independent part, which is typical for symmetric ternary compositions. 
The form of the fifth choir In Winter recalls the structure of the first part of the previous issue. It is based on a period of a non-repetitive structure, consisting of two sentences that are not the same in terms of thematism and scales, varied in number, which can be expressed by the scheme:

\begin{tabular}{|c|c|c|c|}
\hline \multicolumn{2}{|c|}{$\mathrm{A}$} & \multicolumn{2}{c|}{$\mathrm{A}_{1}$} \\
\hline $\mathrm{a}$ & $\mathrm{b}$ & $\mathrm{a}_{1}$ & $\mathrm{~b}_{1}$ \\
\hline Es - B & Es & Es $-\mathrm{B}$ & Es \\
\hline $3 \mathrm{t}$. & $4 \mathrm{t}$. & $3 \mathrm{t}$. & $4 \mathrm{t}$. \\
\hline
\end{tabular}

The structure of this period is not quite common. The first sentence is much more unstable. The main tonality - Es-dur - is fixed in the first bar, and then it is not only unfixed, but also leveled in the movement directed to the domain of the dominant B-dur (t. 3). In contrast to the first sentence, the second one focuses on the basic tonality of Es-dur, in which the voltage drops (t. 4-7). In general, the second half of the period is more stable than the first one; the dynamics of processes in it is aimed at fixing stability. Such an unusual construction can be explained by the general dramaturgy and the thematically shaped development of the whole form, which clearly has signs of variation.

In the score In Winter it is not difficult to notice a figurative "modulation": from the realm of winter and death, the composer brings the listener to the bright sphere of spring, the allconquering life. The solution of this transition is interesting. The melodic material remains practically the same, only rhythm, harmony and texture vary. Thus, in the first sentence of the second part, Hindemith uses an enharmonic substitution of sound ges for fis, as well as harmonic changes in the cadence: in the first period, the sequence $\mathrm{VI}_{6}-\mathrm{VII}-\mathrm{II}_{2}-\mathrm{V}(\mathrm{t} .3)$, and in the second $-\mathrm{II}_{7}-\mathrm{VII}_{6}-\mathrm{II}_{7}-\mathrm{V}_{6} /_{4}(\mathrm{t}$. 10).

In the second sentence of the second part, the melody, as in the previous one, remains the same, but is affected both by harmonic and rhythmic changes. Hindemith removes imitational calls of male and female voices used in the first period and dissects the texture in a different way: the soprano parts are echoed by the remaining three voices (violas, tenors, basses), decimas, which dilute the choral texture, appear instead of the quartet accords of the male chorus. A fracture occurs in a dynamical way as well: from the zone forte and fortissimo, the composer brings the listener to the soft, tender sonority of piano and pianissimo (t. 11-14).

As I.G. Konova notes, "in the texts of culture all elements play a role, meaning is transmitted through all elements: a separate word, all musical elements, their unions, and the whole work have a semantic character" (Konova, 2013: 26). In this work, Hindemith treats the same musical material differently, changing only certain details in harmony, texture and dynamics, as a result of which there is a figurative and emotional "modulation", while the form acquires the features of a couplet variation.

In the sixth choir Fruit Garden the composer turned to a simple ternary reprise form, in which the first part is a square period $(4+4)$, the middle is built on a new theme, and the reprise almost literally (with minor changes) repeats the exposition.

The architectonics is this:

\begin{tabular}{|c|c|c|c|c|c|}
\hline \multicolumn{2}{|c|}{ A } & \multicolumn{2}{c|}{ B } & \multicolumn{2}{c|}{$\mathrm{A}_{1}$} \\
\hline $\mathrm{a}$ & $\mathrm{b}$ & $\mathrm{c}$ & $\mathrm{d}$ & $\mathrm{a}_{1}$ & $\mathrm{~b}_{1}$ \\
\hline $\mathrm{G}$ & $\mathrm{G}$ & $\mathrm{h}$ & $\mathrm{a}-\mathrm{C}-\mathrm{a}$ & $\mathrm{G}$ & $\mathrm{G}$ \\
\hline $4 \mathrm{t}$. & $4 \mathrm{t}$. & $4 \mathrm{t}$. & $7 \mathrm{t}$. & $4 \mathrm{t}$. & $4 \mathrm{t}$. \\
\hline
\end{tabular}

The peculiarity of the exposition period is the periodicity of the summation structure: both sentences have a similar structure, the basis of which is the summation principle $(1+1+2)$, which certainly gives an impulse for further development. So, in the middle part, a new thematic material appears, designed, in analogy with the exposition, on the principle of summation, albeit with a violation of the 
squareness: $2+2+7$. In terms of harmony this part is brightly unstable and passes through a series of tonalities $(h-a-C-a)$, ending at the triad of the second stage.

Let us emphasize that this chorus is an example of a polyfigured type of dramaturgy, where a "deviation" from a light, serene contemplation to grief and sadness (middle part, t. 9-19), followed by a return to the original (t. 20-27), happens. When comparing the exposure to the middle, one can see the reason for such a sharp change of the imaginary sphere: these are cardinal changes in all coordinates of the musical texture. There is minor (h-moll, a-moll) instead of a soft major diatonic (G-dur), there is a mixed writing style (a combination of simultaneity of different types of presentation imitative and contrast polyphony) instead of a stable homophonic texture with its stratification into two strata "relief and background", which leads to a culmination, located in the second half of the middle part that is the point of "golden section" (t. 16-17). Naturally, with such changes, associated primarily with the restructuring of the image-genre sphere, there is a vivid contrast between the extreme parts and the middle one.

In general, the choir has a wave dramatic profile, which is achieved mainly by textural means. Thus, the first part is based on the principle of dialogic opposition of two layers, namely by the leading voice (soprano part) and the three-voice chorus (viola, tenor, bass), which will counterpoint the main theme (t. 1-8). The middle part is rich in shifts of various types of presentation and is distinguished by a complex textural organization. The first four bars combine features of imitative and contrast polyphony: the two-voice canon of soprano and tenors on the lyrical theme is combined with short recitative phrases of violas that sound on the background of the organ point of the bass, which reveals, in addition to polyphony, features of homophony (t. 9-12). Then there is a sharp change in the types of texture: the accord-harmonic style with a monorhythmic movement of all voices (t. 13-14) is replaced by a contrast-polyphonic one, which arises as a result of the gradual complication of choral parts and their individualization (t. 15-19). In the reprise the invoice forms of the exposition return.

Thus, the principle of dialogic opposition of two layers, given in the exposition, is carried through the entire work, and in this case the functions of the elements of the musical texture change in different sections.

Observing the entire work as a whole, one should note a single line of through drama: from the multifigured nature of the first group of choruses dominated by a light calm-serene contemplation (Fallow Deer, Swan, If Everything Passes), to a more contrast (polyfigured) second one (In Winter, Spring, Fruit Garden), where there are emotional-shaped "deviations", as already mentioned above.

The principle of mirror symmetry is also manifested in the architectonics of the cycle. Thus, simple ternary forms in which the first and sixth choirs are written, forming an arch, frame simple binary reprise compositions, which became the basis for all other issues (No. 2-5).

At the same time, using typical traditional forms, having a very precise structure, strictly adhering to the classical principles of formbuilding, the composer organically combines them with modern writing techniques, as a result of which each cycle choir acquires its unique, individual appearance.

Of particular interest is the thematism of Six Songs, which is characterized by melodic ingenuity, intonational freedom, astringency of harmony, logical completeness. The themes of the choirs are lyrically soft, plastic, the features of the German folk song are clearly embodied in them, which is manifested in the smoothness of the 
line except for episodic jumps to wide intervals, which are filled with the incoming movement, only the tertiary and second passages (and repetitions of sound) are present in the melody. The melodiousness and softness are combined in them with a wavy, rounded and balanced melodic pattern, typical for lyrical melodies.

According to Asaf'ev, "Hindemith is the strongest and most generous melodist. His imagination in this respect is inexhaustible. But his melodies are not melodic in the philistine idea of a melody. They are too tart and, at the same time, capricious. Spontaneously capricious. Hindemith's melodies are not clocked and are not conditioned by the usual harmonic successions of tonic - dominant. They do not know the formally compulsory cadence turns. They are free and at the same time natural, as well as the picturesque pattern is free by the impression produced, but, nevertheless, deeply legitimate. Even more so: as free and regular the flight of birds is" (Asaf'ev, 1975: 203).

Hindemith's thematism differs in its characteristic and stable features. It was elaborated by the composer very carefully and became an essential phenomenon of Western European music of the $20^{\text {th }}$ century, along with the widespread "athematic", "fractional", "embryonic" structures of some composer styles. The sources of Hindemith's themes are diverse: from the Old German folk song and the Gregorian chant to the popular music of the $20^{\text {th }}$ century.

As noted by the researchers T.N. Levaia and O.T. Leont'eva, "the themes of the composer are always deeply modern, expressing their own and, undoubtedly, actual for the time pathos of the composer. Through the genre and intonation model, singularity, elevation, national character are expressed in some cases, while parody, playfulness, stylistically refreshed naive gaiety are expressed in others" (Levaia, Leont'eva, 1974: 336).
The choruses of the analyzed cycle are characterized by such features of melody as non-periodicity of structure and free metric organization, relief of melodic grain, imparting brightness and individuality to themes, intonational multifaceted of thematism and its concentration.

Thus, in the first chorus of Fallow Deer cycle, along with rehearsal repeats of the sounds of middle voices (viola, tenors) and the progressive, deepening movement of the bass line, the soprano melody has a developed melodic line that evokes associations with the amazing plasticity of the graceful animal. In this case, a special role in the chorus is played by the initial intonation - the trichord in the quint $\left(\mathrm{a}^{1}-\mathrm{h}^{1}-\mathrm{e}^{2}\right)$. Being a melodic theme grain, it frames the first part (t. 1-4), sounds in the middle in the pre-culmination (t. 9-10), and also completes the entire composition. Thus, this trichord intonation acquires a key importance and belongs to the number of essential factors that unify the melody and give it the features of inner wholeness and completeness.

Hindemith reaches the relief of the melodics by the character of the interval structure (quartoquintine jumps, diatonic and pentatonic turns, movement along the chord line), and also the peculiarity of the modal style: thanks to the intonational means, the tonal centers fis-moll, cis-moll, Mixolydian E-dur, related to the basic structure of A-dur are outlined in the leading melodic line (t. 1-4).

The polyphonic nature of the composer's thinking manifests itself in the profound individualization of all voices, as well as in the use of imitations in the middle of the choir ( $t$. 5-9), which brings revival into a relatively stable and simple musical texture.

In the second chorus Swan, the composer seems to change the voices in some places: the repetitions of the quintal $h$ tone in the soprano part are accompanied by a second movement of 
the remaining voices down. The music of the choir depicts the gentle sliding of a royal bird along the river surface and the scarcely noticeable swaying of water (t. 1-5).

The melody of the second part evokes associations with a slight sweep of the wings of the beautiful swan. Here again, Hindemith applies the imitative elements of the exposition. This is how the composer delivers the subtle emotional excitement, the shakiness of dreams and revery (t. 5-8). Further, in the reprise, the original soprano melody shifts to the bass line, and a relatively new theme appears in the upper voice, which moves gently, singing for the intonational foundations of the Mixolydian E-dur (t. 12-17). The melodic line has smooth character, only quarto-quint jumps are occasionally encountered, which are balanced by the on-going movement, which gives the features of proportionality and harmony to thematism.

The melody of the third chorus If Everything Passes is distinguished by an easy and mobile character (t. 1-8). The endless run of time, the delicate play of moods of sadness, doubt and hope is transmitted through the rapid movement of the eighths in the size of 6/8 (the pace of Vivo). The regular alternation of ups and downs, the variant principle of deployment, quiet dynamics (piano, pianissimo) and the stroke of non legato, unwittingly associated with the inexorable movement of the clockwise, embody a whole gamut of semantic and emotional shades.

In the fourth chorus Spring Hindemith does not neglect the romantic methods of expressiveness. The composer sees the melodiousness in this work as a means and the goal of the composition. Harmony is dominated by the richly chromatinized diatonic As-dur with an abundance of seventh chords, nonakkords, quarts, quintakords of side steps (II, III, VI, VII). While in the melodics, the method of decreasing variation of diatonic steps is widely used: $b$-bes, $c$-ces, $f$-fes, $g$ - ges. Such a variation of the steps gives the theme a special modal harmonic tone. In the musical texture of the choir, combined modal formations arise: through the Myxolidian As-dur, the Phrygian as-moll (t. 1-7) shines through, the natural and the Phrygian gis-moll is represented in combination with the Ionian E-dur (t. 15-17). The texture of the work also differs by a flexible and variable contour.

The intonational structure of the fifth chorus In Winter is saturated with sharp dissonant consonances. The melodics moves abruptly, relying on the main Es-dur steps: the fifth, the third, the first. In this score, the role of the rising quartet is most vividly revealed, which, together with wide jumps to the seventh, sixth and fifth, gives the theme pathetic features, a hint of oratorical pathos (t. 1-7).

In the choir Fruit Garden, completing the cycle, the song melody of lyrical nature is entrusted to the soprano, which is accompanied by other voices (altos, tenors, basses) performing the function of harmonic support in the extremes (t. 1-8). In the leading melodic line, one can note chromatic abortions: the lowered second, third and sixth steps. In the middle part there are deviations in h-moll, a-moll, C-dur, using a variant increase in diatonic steps (gis, fis), which emphasizes the Dorian color of the minor, and also outlines the Mixolydian C-dur.

In B.V. Asaf'ev's opinion, “ Hindemith's feel of line corresponds to the feel of a harmonic background, in other words, it is the ability to intensify the impact of melos in time by surrounding and replenishing it with the help of vertical sound formations. These various chord complexes, shading the melodic relief, do not bind the freedom of "self-determination" of the melos. It is curious that on Hindemith's texture it is possible to trace the gradual transformation of the characteristic impressionistic skills that so recently dominated as independent and final tasks 
into temporary techniques serving as one of the auxiliary means for new expressive aspirations and new conquests" (Asaf'ev, 1975: 204).

An important role in the final chorus is played by the initial intonation that is the trichord in the quinta, which in different versions permeates the entire musical texture of the work $\left(d^{2}-g^{l}-a^{l}, g^{l}-a^{l}-d^{2}, e s^{l}-a s^{l}-b^{l}\right)$. Forming the intonation arch with the first choir Fallow Deer, it acquires a key value in the cycle, and along with other expressive means it contributes to the compositional harmony and integrity of the cycle.

Summing up, we can say that Six Songs to the Lines of R. Rilke is a mature, masterful composition that is distinguished by all the peculiar features of Hindemith's style. It is typical of the composer from the point of view of the theme, the problems, and the musical language. This is evidenced by the type of dramatic development and the dynamic profile that is not separated from it, as well as by the composition, internally integral, fastened by the strict logic of subordination of individual parts to the whole, the features of the modal harmonic and tonal structure, the organic synthesis of thinking and language of the $20^{\text {th }}$ century with the traditions of the baroque musical culture, brilliant mastery of the expressive means of the choir.
Apparently, this cycle appeared in connection with Hindemith's desire to democratize his work. In it, he refers to the Old German folk song, which symbolizes a high ethical principle for the composer. The vocal style of the work is liberated from the concert-virtuosic beginning, which is unnecessary in this genre, and colorful effects, which speaks of Hindemith's profound knowledge of the possibilities of the human voice, his interest in living sound, timbre, and color. The flawless technique of part-writing, a variety of tempo, dynamics and texture, purity and freshness of sound, special richness of the language - all this allows us to refer this cycle to the original masterpieces of the choral miniature.

Describing Hindemith's cantata Serenades (or. 35) for soprano, oboe, viola and cello, B. Asaf'ev wrote, "The purity of style, the perfection of technique, the saving of money and, at the same time, the fullness and freedom of expression, the taste and freshness of thought, the restraint of feeling, with deep sincerity and simplicity - all these qualities merged into a harmonic orderly whole in these serenade cycles and formed an exquisitely modern chamber product" (Asaf'ev, 1975: 208). These words can be fully attributed to Six Songs to the Lines of $R$. Rilke, which rightfully entered the golden fund of choral music of the $20^{\text {th }}$ century.

\footnotetext{
Instructions are given for the following edition: Hindemith, P. (1969). Six songs to the texts of the original French poems by R. Rilke for a mixed choir without accompaniment. Russian text by S. Volsky. Leningrad, Muzyka, 28 p.
}

\section{References}

Asaf'ev, B.V. (1975). Elementy stilia Khindemita [The elements of Hindemith's style], In Zarubezhnaia muzyka XX veka [The foreign music of the $20^{\text {th }}$ century]. Moscow, Muzyka, 198-209.

Fedoseev, I.S. (2010). Paul' Khindemit [Paul Hindemith], In Istoriia zarubezhnoi muzyki [The foreign music history], 6. St. Petersburg, Kompozitor, 403-466.

Konova, I.G. (2013). Kognitivno-semioticheskie kontseptsii analiza verbal'no-muzykal'nogo teksta avtorskoi (bardovskoi) pesni [The cognitive and semiotical concepts of the analysis of the verbal and musical text of the author's (bardic) song], In Voprosy cul'turologii [The culturology issues], 4, 20-28. 
Kostiuk, E. (2012). Telesnost' kak kharakteristika muzykal'noi cul'tury XX- nachala XXI veka [The corporality as characterization of music culture of the $20^{\text {th }}$ - beginning of the $21^{\text {st }}$ century], In Voprosy cul'turologii [The culturology issues], 12, 62-66.

Levaia, T.N. (1979). O stile Khindemita [About Hindemith's style], In Paul' Khindemit. Stat'i i materialy [Paul Hindemith. The articles and materials]. Moscow, Muzyka, 262-299.

Levaia, T.N., Leont'eva, O.T. (1974). Paul' Khindemit. Zhizn 'i tvorchestvo [Paul Hindemith. Life and creation]. Moscow, Muzyka, $448 \mathrm{p}$.

Leont'eva, O.T. (1962). Karl Orf i Paul' Khindemit [Carl Orf and Paul Hindemith], In Muzyka i sovremennost'. Sbornik statei [Music and contemporaneity. Collected articles], 1. Moscow, 243-302.

Skrebkova-Filatova, M. (1979). Ob osobennostiakh razvitiia faktury v kamernykh khorakh Khindemita [On the features of the texture's development in Hindemith's chamber choruses], In Paul' Khindemit. Stat'i i materialy [Paul Hindemith.The articles and materials]. Moscow, Muzyka, 179-209.

Sokhor, A. (1980). Oratorial'no-kantatnaia i khorovaia muzyka [Oratory, cantata and choral music], In Muzyka XX veka. Ocherki v dvukh chastiakh [Music of the $20^{\text {th }}$ century. The essays in two parts], 1 (3). Moscow, Muzyka, 312-345.

Ter-Oganezova, I. (1979). "Ludus tonalis". Osnovnye osobennosti formoobrazovaniia ["Ludus tonalis". The main features of formation], In Paul' Khindemit. Stat'i i materialy [Paul Hindemith.The articles and materials]. Moscow, Muzyka, 83-113.

Varunts, V. (1988). Muzykal'nyi neoklassitsizm: Istoricheskie ocherki [Musical neo-classicism: historical essays]. Moscow, Muzyka, 80 p.

Varunts, V. Tsikl "Kammermusik" (k voprosu o neoklassitsizme P. Khindemita) [The cycle Kammermusik (to the question about P. Hindemith's neo-classicism)], In Paul' Khindemit. Stat'i i materialy [Paul Hindemith.The articles and materials]. Moscow, Muzyka, 143-178.

\section{Хоровой цикл Пауля Хиндемита «Шесть песен на стихи Р. Рильке» (некоторые черты стиля)}

Л.Л. Равикович

Красноярский государственный институт искусств Россия, 660049, Красноярск, ул. Ленина, 22

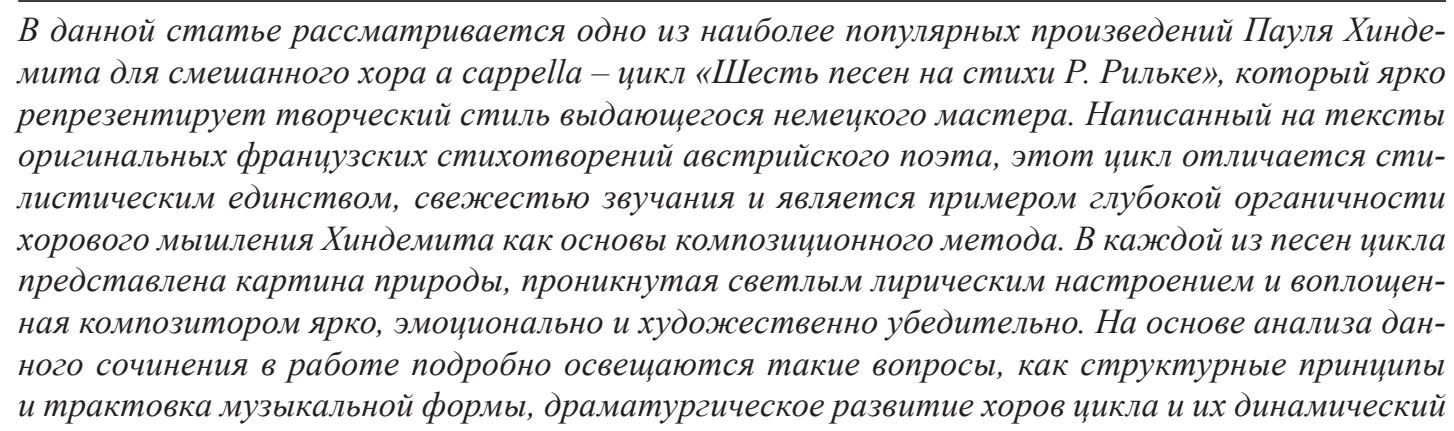


профиль, анализируются средства выразительности, в частности, интонационно-мелодический и ладогармонический язык произведения, его фактурная организация.

Ключевые слова: композиция, форма, драматургия, тональность, гармония, фактура.

Научная специальность: 24.00.00 - культурология, 17.00.00-искусствоведение. 